\title{
Effect of Rhamnolipids on Pathogenicity Characteristics of Microorganisms in Organic Compost
}

\author{
Ciamak Ghazaei ${ }^{1 *}$ (D)
}

1. Department of Microbiology, University of Mohaghegh Ardabili, Ardabil, Iran.

$\begin{gathered}\text { Use yur devic to scan } \\ \text { and read the article online }\end{gathered}$
search in Molecular Medicine. 2021; 9(1):39-50. https://doi.org/10.32598/rmm.9.1.5
dolichttps://doi.org/10.32598/rmm.9.1.5

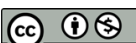

Article Type:

Research Paper

Article info:

Received: 21 Nov 2020

Revised: 26 Dec 2020

Accepted: 12 Jan 2021

Keywords:

Rhamnolipid, Surfactant, Antimicrobial, Bacillus stearothermophilus, Protease

\begin{abstract}
A B S T R A C T
Background: Rhamnolipids are hydrophilic glycolipids, often classified as biosurfactants. They are produced by different bacterial species. Rhamnolipids are extensively studied in biological research because of their interesting features like antimicrobial, antifungal, and antiviral activities.

Materials and Methods: To study the antimicrobial effect of rhamnolipid, we conducted a crosssectional study on the eight different pathogenic bacterial strains from November 2019 to June 2020. These bacterial strains were isolated from the organic compost. Both disk diffusion and broth microdilution methods were used to evaluate the inhibitory effects of rhamnolipids on these pathogenic bacteria. Also, protease and amylase enzyme activities were evaluated in these eight bacterial isolates.

Results: For Bacillus stearothermophilus, within the area of $31.5 \mathrm{~mm}$, no growth was observed, hence proving the inhibitory effect of rhamnolipid. After calculating the Minimum Inhibitory (MIC) and Minimum Lethal Concentrations (MLC) for each bacterial strain, it has been found that the studied bacteria were more susceptible to rhamnolipids than most of the antibiotics. Strains were also quantified for their enzymatic activity of proteases and amylases. The bacterial strains of Bacillus stearothermophilus, Brevibacillus brevis, Bacillus licheniformis, and Bordetella petrii showed maximum protease activity. Whereas Escherichia coli, Enterococcus faecalis, Enterobacter aerogenes, and Pseudomonas aeruginosa showed high amylase activity.
\end{abstract}

Conclusion: Rhamnolipids can be used as a potential antimicrobial agent for treatment of infections.

\section{Introduction}

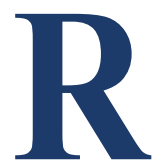

hamnolipids are extensively studied glycolipids. They are originally produced by Pseudomonas aeruginosa and various bacterial species. They are often known as "biosurfactants." They consist of a hydrophilic group, having one or two Lrhamnose molecules bonded via glycosidic linkage to one or two $\beta$-hydroxy fatty acids, which is the hydrophobic part of the molecule. Mono-rhamnolipids consist of a single rhamnose molecule, whereas di-rhamnolipids have two rhamnose molecules $[1,2]$.

\footnotetext{
* Corresponding Author:

Ghazaei Ciamak, PhD.

Address: Department of Microbiology, University of Mohaghegh Ardabili, Ardabil, Iran.

Phone: +98 (45) 33512081-9

E-mail: ciamakghazaei@yahoo.com
} 
Rhamnolipids are also produced at an industrial scale by microbial fermentation of $P$. aeruginosa in large titers. They are extensively studied because of their excellent physicochemical properties and ability to reach elevated levels of fermentation titers. Their properties change according to the change in length of fatty acids, which makes them a diverse group of molecules [2]. Rhamnolipids are amphipathic surfactants. So they reduce the surface tension, which helps the bacteria to adhere to different surfaces. Some microbes produce rhamnolipids only when hydrocarbons are used as a carbon source. Some rhamnolipids producing strains cause nosocomial infections, especially in people with a weakened immune system [2].

One of the most interesting features of biosurfactants such as rhamnolipids is their wide applications in industrial and biological arenas. In industries, they are used in petroleum products, food processing, cosmetics, bioremediation, and pharmaceutical products. They are extensively used in biological research because of their antimicrobial, antifungal, and antiviral activities. Rhamnolipids at a concentration of about $0.4-10.0 \mathrm{mg} / \mathrm{L}$ inhibit the growth of harmful algae Heterosigma akashiwo and Prorocentrum dentatum. Rhamnolipid AT10 isolated from $P$. aeruginosa showed antimicrobial activity against E. coli (32 mg/mL), Mycobacterium phlei (16 mg/mL), and Staphylococcus epidermis $(8 \mathrm{mg} / \mathrm{mL})$. It has also demonstrated its antifungal property against Aspergillus niger $(16 \mathrm{mg} / \mathrm{mL})[4,5]$. They are also used in cosmetics, treatments of skin diseases, wound healing [6-9].

Rhamnolipids are used as cleaners and detergents. They are active agents for surfaces and behave as natural emulsifiers, which lead to widespread use in soaps, shampoos, compositions of detergent, and laundry products $[10,11]$. They are also used to improve soil quality in soil bioremediation and as biopesticides [12]. The rhamnolipids production cost is high because of costly raw materials used for bacterial fermentation. However, processes used to obtain purified products limit the rhamnolipids' application on an industrial scale [13]. Therefore, much research has been done for reducing costs and increasing yield by using cheap substrates [14], and optimizing production conditions [15]. The different process of production and screening natural strains and production strategies of genetic engineering needs more efficient methods for separating purifying rhamnolipids homologue. Numerous research studies have evaluated substrates at low cost, developed active fermentation processes to screen new strains, and increases rhamnolipids yields [16]. Rhamnolipids have great potential to replace synthetic medicines because of their lower toxic- ity and higher antimicrobial activity. Much research has been carried out where rhamnolipids are mass-produced from $\mathrm{P}$. aeruginosa and tested for their anti-bacterial potential on different strains $[17,18]$.

During the composting process of organic materials/ wastes, humus-rich and biostable products are produced, which can improve the land and help to fertilize the plants [19]. Many studies have reported the presence of different mesophilic, thermophilic, and thermotolerant pathogenic microorganisms in organic compost. They can survive in the compost for a longer period. During the thermophilic phase, thermophilic bacteria grow and colonize in compost. After completing the thermophilic phase of the composting, mesophilic microorganisms grow fast in the compost $[20,21]$. Even antibiotic-resistant microorganisms have been found in organic compost, where animal wastes have been used to prepare organic compost [20]. Many studies have proven that using such organic fertilizers causes the contamination of such pathogenic microorganisms in the soil and the vegetables/plants grown in such soil [20, 22-24]. This process could risk the transfer of pathogenic microorganisms to humans through such organic vegetable consumption.

Rhamnolipids are biosurfactants and can improve compost quality. They can directly or indirectly affect the growth of microorganisms and their enzyme production and helping in the microbial bioremediation processes, too [25]. Haba et al. have explained the antimicrobial effect of rhamnolipids [26, 27]. Hence, this study will evaluate the potential antimicrobial effect of rhamnolipids on the pathogenic microorganisms in the organic compost, which could help reduce the risk of the transfer of pathogenic microbes through the consumption of organically grown vegetables/fruits. In the current research, some bacterial strains are isolated from organic compost, and rhamnolipids are studied on them. The results are then compared to bacterial inhibition by synthetic antibiotics to get a better notion about the inhibitory capability of the rhamnolipids.

\section{Materials and Methods}

\section{Isolation of pathogenic bacteria from compost}

To isolate bacterial strains from composted organic matter, sampling of the compost production process was carried out at Ardebil Composting Plant. The obtained compost was first sifted to remove larger elements like stones, wood, small branches, etc. Then $100 \mathrm{~g}$ of the compost mixture was added to $500 \mathrm{~mL}$ of saline solution and stirred on the shaker for three $h$. The purpose 
of such vigorous shaking is to clean up the sample by removing interference before analysis. After solid-phase saturation, the supernatant liquid phase was separated, which is to be used for media inoculation. The next step is to enrich microbes in the compost sample to obtain the isolated bacterial colonies on solid or liquid cultures. For this purpose, $10 \mathrm{~mL}$ of the above extract was added to $100 \mathrm{~mL}$ of four different culture media (Quelab, Canada), which use cellulose, xylene, starch, and protein as a carbon source, respectively. All these media after inoculation were placed in the rotary shaker incubator at $140 \mathrm{rpm}$ with a temperature range of $37^{\circ} \mathrm{C}-62^{\circ} \mathrm{C}$ for one week. It was done to isolate the mesophilic bacteria and the thermophilic bacteria. After one week, $5 \mathrm{~mL}$ of each medium was added to $100 \mathrm{~mL}$ of the new medium of the same material. It means that $5 \mathrm{~mL}$ from the cellulose medium was transferred to $100 \mathrm{~mL}$ of the new cellulose medium. The same process was carried out for the other three media. These newly inoculated media were then incubated under the same conditions (140 rpm and a temperature range of $37^{\circ} \mathrm{C}-62^{\circ} \mathrm{C}$ for one week). After one week of incubation, the same process was repeated, but this time only $1 \mathrm{~mL}$ from each medium was transferred to the new medium [28].

This process of microbial concentration was repeated several times to eliminate the opacity created by adding the former to the new environment caused by soil particles. Different dilutions were prepared from each of the last media of the enrichment process, and appropriate dilution of each medium was purified on a solid agar medium of the same material (cellulose, xylene, starch, and protein). Different strains were isolated based on the differences in bacterial colonies, and individual colonies were purified on a complete agar medium. Finally, by reculturing, each strain was purified in the liquid medium, the ability of each bacterium to grow was demonstrated. Morphological analysis like colony morphology, gram staining, bacterial motility; and biochemical tests like oxidase, catalase, and sugar tests such as fermentation tests of glucose, sucrose, and lactose were carried out to identify the isolated bacterial strains, as per Bergey's Manual of Systematic Bacteriology [29].

\section{Preparation of bacterial strains}

Bacterial isolates were cultured in Mueller-Hinton agar medium (Merk, Germany) and incubated at $37^{\circ} \mathrm{C}$ for $24 \mathrm{~h}$. Mueller-Hinton is a non-selective, non-differential media that are commonly used for antibiotic susceptibility testing. Subsequently, a few drops of the bacterial suspension were transferred to the Mueller-Hinton broth medium to achieve a turbidity equivalent of $0.5 \mathrm{McFarland}$ standard (1.5 x 108 bacterial concentration per $\mathrm{mL} / \mathrm{CFU} / \mathrm{mL}$ ) [30].

\section{Rhamnolipid preparation}

Rhamnolipid powder (Canada, Toronto Research Chemicals Inc.) was purchased and sequential dilutions of $1000,500,250,125$ and $50 \mathrm{mg} / \mathrm{mL}$ were prepared in $<0.1 \%$ of dimethyl sulfoxide (DMSO) solution [4, 31]. Preparations of rhamnolipid dilutions were used for antibacterial studies.

\section{Evaluation of the antimicrobial effect of rhamno- lipid on isolated bacteria}

Bacterial suspensions in Mueller-Hinton broth were used to determine qualitative and quantitative antimicrobial activity. In the qualitative method, the Kirby-Bauer agar diffusion method (more commonly referred to as the disk-diffusion method) was used. The first step is the aseptic inoculation of isolated bacterial strains suspensions on Mueller-Hinton agar medium plates. Then, for examining the antibacterial properties, blank paper disks (made of antibody medicine) were placed at a fixed distance from each other on the plates. Then, about $20 \mu \mathrm{L}$ of prepared rhamnolipid concentrations containing 1000 , $500,250,125$, and $50 \mathrm{mg} / \mathrm{mL}$ diluted in dimethyl sulfoxide solution was added to the disks. Gentamicin antibiotic disk $(10 \mu \mathrm{g} / \mathrm{mL})$ was used as a positive control in each plate. The prepared plates were then incubated overnight at $37^{\circ} \mathrm{C}$. After overnight incubation, the area of no growth (inhibition zones) was measured in $\mathrm{mm}$ [32].

\section{Antibiotic susceptibility test}

The antibiotic susceptibility test by disk diffusion method was also performed with standard synthetic antibiotics, and the result of the two tests was compared with the tables provided by the Standard Clinical and Laboratory Institute, which provide standards and guidelines for susceptibility testing (CLSI) [30]. To ensure the results of each of the different concentrations of rhamnolipid and antibiotics, these tests were repeated three times for each bacterial strain. Also, quantitative tests were performed to determine the minimum inhibitory (MIC) and minimum lethal concentrations (MLC) of rhamnolipid. Thus, the minimum inhibitory concentration was tested in a sterile microtiter plate using a broth microdilution method. To evaluate the performance of rhamnolipids as a potential antimicrobial agent, MIC and MLC values were calculated by using the broth microdilution method for the turbidity observed at an optical density of 650 $\mathrm{nm}$ as an observed bacterial growth in the broth. Then 
the results were compared with the standard antibiotic Gentamicin $(10 \mu \mathrm{g} / \mathrm{mL})$. The assessment was done to evaluate bacteria's susceptibility against the rhamnolipids compared to the standard antibiotics. After culturing bacteria on the Müeller-Hinton agar medium, the observed colony was transferred to the broth with the help of a sterile swab. The broth is incubated at $37^{\circ} \mathrm{C}$ until the growth reaches turbidity equal to that of $0.5 \mathrm{McFarland}$ standard. As per CLSI recommendations, the culture was adjusted with sterile broth to give turbidity equivalent to the McFarland 0.5 standard $(1.5 \times 108 \mathrm{CFU} / \mathrm{mL})$ [30]. First, $100 \mu \mathrm{L}$ of inoculated Mueller-Hinton broth was added into the six wells of the microtiter plate to get the desired microplate dilutions. Then, $100 \mu \mathrm{L}$ of rhamnolipid was added to the first well $(1000 \mathrm{mg} / \mathrm{mL}$; the highest concentration of the rhamnolipid), and diluted concentrations of rhamnolipid (500, 250, 125, and 50 $\mathrm{mg} / \mathrm{mL}$ ) were serially added from the second, third, and so on to the sixth well. Celle in the wells was adjusted for 0.1 optical density. After incubation at $37^{\circ} \mathrm{C}$, the turbidity was measured by spectrophotometry at $650 \mathrm{~nm}$ after every $12 \mathrm{~h}$ interval for the next three days to assess the bacterial growth. In another well, $100 \mu \mathrm{L}$ of diluted suspension (Nutrient broth) equivalent to half McFarland tube was added as a blank [4, 33]. After overnight incubation at $37^{\circ} \mathrm{C}$, the tubes were evaluated for macroscopically visible evidence of bacterial growth in the form of turbidity. Basic controls like culture medium and microbes were also separately noted for the presence or absence of bacterial growth in the specialplate.

By definition, the first well without turbidity (lowest) is placed as the minimum inhibitory concentration. Also, the minimum lethal concentration (MLC) test was determined according to the results of the minimum inhibitory concentration (MIC). The wells in which bacterial growth was entirely stopped by sterile swab sampling were cultured on nutrient agar medium and incubated at $37^{\circ} \mathrm{C}$. After $24 \mathrm{~h}$, the lowest concentration of rhamnolipid in which the bacteria did not grow was reported as the MLC [34].

\section{Enzyme activity of the isolated strains}

The next step was the determination of the enzyme activity of these isolated strains. There are different enzymes synthesized and secreted by microorganisms required for the degradation of organic waste during composting. Different enzymes like protease, amylase, lipase, and cellulase are involved in the degradation process. Hence, isolated bacterial strains were screened to produce the two enzymes: protease and amylase [35, 36]. The enzymatic activity of amylase and protease was quantified using spectrometry. The amylase activity was determined using the DNS solution. For this purpose, $1 \mathrm{~mL}$ bacterial suspension was added in a test tube, to which $1 \mathrm{~mL}$ of prepared starch solution was added. Phosphate buffer solution in bacterial suspension acts as a control. Both test tubes were incubated at $37^{\circ} \mathrm{C}$ for 30 minutes. After incubation of $2 \mathrm{~mL}$ of DNS solution was added to each test tube, they were placed in a boiling water bath for 15 minutes. After cooling, the absorption was measured at $540 \mathrm{~nm}$. This process was carried out for each bacterial strain [37].

For the determination of protease activity, $1 \mathrm{~mL}$ of casein (Padtanteb Co. Iran), which acts as the enzymesubstrate, is added in a test tube with $1 \mathrm{~mL}$ bacterial suspension. It is incubated at $37^{\circ} \mathrm{C}$ for 10 minutes. After 10 minutes of incubation, Trichloroacetic acid TCA was added to stop the reaction. The test samples are then passed through a $0.45-\mathrm{m}$ polyethersulfone syringe filter. After this, $1 \mathrm{~mL}$ of sodium carbonate and $1 \mathrm{~mL}$ of Folin's reagent are added. Absorbance was taken at $660 \mathrm{~nm}$. This procedure was carried out for each bacterial strain [38].

\section{Results}

\section{Isolation and identification of pathogenic bacteria from compost}

From the morphological and biochemical tests, eight isolated bacterial strains from the organic compost were identified as per Bergey's Manual of Systematic Bacteriology. The colony morphology was studied on the bacterial culture plate, and morphological characteristics of the colony grown on the plate, the gram staining, and motility characteristic are observed and mentioned in Table 1.

The biochemical tests like evaluating the different types of sugars (glucose, lactose, and sucrose), catalase and oxidase creation, and The Voges-Proskauer (VP) test determine whether microorganisms can produce acetyl methyl carbinol from glucose fermentation. The biochemical characteristics of the bacterial colonies are mentioned in Table 2.

Evaluation of the antimicrobial effect of rhamnolipid on pathogenic bacteria

As different concentrations of rhamnolipid were used to determine the inhibitory zone on the bacterial isolates, it was found that $1000 \mathrm{mg} / \mathrm{mL}$ of rhamnolipid has the maximum antibacterial activity against different pathogenic strains. Gentamycin antibiotic disk (Padtanteb, Co.) with a concentration of $10 \mu \mathrm{g} / \mathrm{mL}$ was used as a positive con- 
Table 1. Morphological characteristics of bacterial strains

\begin{tabular}{|c|c|c|c|c|}
\hline \multirow{2}{*}{ Bacterial Strains } & \multirow{2}{*}{ Colony Characteristics } & \multicolumn{2}{|c|}{ Cell Characteristics of Bacteria } & \multirow{2}{*}{ Motility } \\
\hline & & Gram Nature & Shape & \\
\hline Enterococcus faecalis & White, circular, smooth, and entire & Gram + ve & Cocci & Non-motile \\
\hline Enterobacter aerogenes & White, circular, smooth, and entire & Gram - ve & Bacilli & Motile \\
\hline Bordetella petrii & White, circular, shiny & Gram - ve & Coccobacilli & Non-motile \\
\hline Pseudomonas aeruginosa & Large and smooth colonies & Gram - ve & Bacilli & Motile \\
\hline E. coli & Circular, Moist, Smooth, and entire margin. & Gram - ve & Bacilli & Motile \\
\hline Bacillus stearothermophilus & Creamy, circular, smooth, entire & Gram + ve & Bacilli & Motile \\
\hline Bacillus licheniformis & Creamy, rough, irregular & Gram + ve & Bacilli & Motile \\
\hline Brevibacillus brevis & Circular, Translucent, Smooth and Coalesce & Gram + ve & Bacilli & Motile \\
\hline
\end{tabular}

trol. The average area of inhibitory zones in $\mathrm{mm}$ for 1000 $\mathrm{mg} / \mathrm{mL}$ of rhamnolipid is given in the Table 3.

Minimum Inhibitory Concentration (Mic) and Minimum Lethal Concentration (MLC)

MIC of rhamnolipid showed the lowest concentration, which can inhibit the visible growth of bacteria, whereas MLC showed the lowest concentration of rhamnolipid that can be lethal for bacteria. Determination of MIC and MLC are important in antimicrobial susceptibility testing. Table 4 demonstrates the inhibitory and lethal effects of rhamnolipid on all eight isolated bacterial strains.

The result was compared to the standard provided by the US Standard Clinical and Laboratory Institute
(CLSI, 2015). The standard antibiotic susceptibility test result in percentage is also given in Table 5. Analysis of the data was carried out by using descriptive statistics and frequency distribution tables. The resulting percentages of different antibiotics were calculated for the eight isolated bacterial strains. The obtained results were further categorized into resistant (R), intermediate (I), and susceptible (S) categories for the eight isolated bacterial strains from the organic compost.

The MIC of rhamnolipid on different isolated bacterial strains was compared with the standard value given by Standard Clinical and Laboratory Institute. Accordingly, it was found that $E$. coli was better inhibited by rhamnolipid $(1000 \mathrm{mg} / \mathrm{mL})$ compared to all other antibiotics. Only amikacin showed better inhibition than rhamnolipid.

Table 2. Biochemical characteristics of bacterial strains

\begin{tabular}{|c|c|c|c|c|c|c|}
\hline \multirow{2}{*}{ Bacterial Strains } & \multirow{2}{*}{ Catalase } & \multirow[t]{2}{*}{ Oxidase } & \multirow{2}{*}{ Voges-Proskauer test } & \multicolumn{3}{|c|}{ Fermentation Tests } \\
\hline & & & & Glucose & Lactose & Sucrose \\
\hline Enterococcus faecalis & 've & 've & $+\mathrm{ve}$ & +ve & +ve & ${ }^{+}$ve \\
\hline Enterobacter aerogenes & +ve & 've & $+\mathrm{ve}$ & +ve & +ve & ${ }^{+}$ve \\
\hline Bordetella petrii & +ve & +ve & $+\mathrm{ve}$ & -ve & 've & 've \\
\hline Pseudomonas aeruginosa & ${ }^{+}$ve & +ve & $-v e$ & +ve & -ve & -ve \\
\hline E. coli & +ve & 've & $-v e$ & +ve & +ve & +ve \\
\hline Bacillus stearothermophilus & ${ }^{+}$ve & ${ }^{+}$ve & - ve & ${ }^{+}$ve & -ve & ${ }^{+}$ve \\
\hline Bacillus licheniformis & +ve & +ve & $+\mathrm{ve}$ & +ve & +ve & +ve \\
\hline Brevibacillus brevis & ${ }^{+}$ve & ${ }^{+}$ve & - ve & -ve & -ve & 've \\
\hline
\end{tabular}


Table 3. Inhibitory effect of rhamnolipid on isolated strains

\begin{tabular}{|c|c|c|}
\hline Isolated Bacterial Strains & Gentamycin (10 $\mathrm{\mu g} / \mathrm{mL})$ (Positive Control) & Area of no Growth $(\mathrm{mm})$ (Rhamnolipids $-1000 \mathrm{mg} / \mathrm{mL}$ ) \\
\hline Brevibacillus brevis & $19.43(\mathrm{~S})$ & 25 \\
\hline Bordetella petrii & $21.90(S)$ & 18 \\
\hline Bacillus stearothermophilus & $20.34(S)$ & 31.5 \\
\hline E. coli & $18.24(\mathrm{~S})$ & 28.4 \\
\hline Enterococcus faecalis & $19.15(\mathrm{~S})$ & 21.5 \\
\hline Enterobacter aerogenes & $18.54(\mathrm{~S})$ & 20 \\
\hline Pseudomonas aeruginosa & $20.72(S)$ & 24.8 \\
\hline Bacillus licheniformis & $19.25(\mathrm{~S})$ & 28 \\
\hline
\end{tabular}

Regarding Bordetella petrii, the inhibitory effect of $1000 \mathrm{mg} / \mathrm{mL}$ of rhamnolipid was higher than all antibiotics except ciprofloxacin, doxycycline, and imipenem which showed better susceptibility for B. petrii. Also, $1000 \mathrm{mg} / \mathrm{mL}$ of rhamnolipid has a better inhibitory effect on Enterococcus faecalis when compared to other antibiotics. However, ciprofloxacin, piperacillin/tazobactam, and co-trimoxazole were more effective in inhibiting the growth of E. faecalis. Regarding Pseudomonas aeruginosa, the inhibitory effect of $1000 \mathrm{mg} / \mathrm{mL}$ of rhamnolipid was higher than other antibiotics effective on this bacterium, but rhamnolipid was found to be less effective than doxycycline and ciprofloxacin antibiotics. The Bacillus stearothermophilus was effectively inhibited by $1000 \mathrm{mg} / \mathrm{mL}$ of rhamnolipid than other antibiotics except doxycycline antibiotic. In Bacillus licheniformis, the inhibitory effect of $1000 \mathrm{mg} / \mathrm{mL}$ of rhamnolipid was higher than other antibiotics effective on this bacterium.
However, rhamnolipid was less effective than the inhibitory effect of ceftazidime on this bacterium.

Enterobacter aerogenes was better inhibited by 1000 $\mathrm{mg} / \mathrm{mL}$ of rhamnolipid than other antibiotics effective on this bacterium. Imipenem, chloramphenicol, and amikacin were more effective than rhamnolipid. Regarding Brevibacillus brevis, the inhibitory effect of $1000 \mathrm{mg} /$ $\mathrm{mL}$ of rhamnolipid was higher than all the antibiotics except doxycycline on this bacterium.

Investigation of enzymatic activity in strains isolated from compost

Analysis of the enzymatic activities of the isolates indicated that these strains differ regarding the enzymatic activity of amylase and protease. Most of the protease activity belongs to the strains of Bacillus stearother-

Table 4. MIC and MBC of rhamnolipid $(\mathrm{mg} / \mathrm{mL})$

\begin{tabular}{ccc}
\hline Strain & MIC $(\mathbf{m g} / \mathbf{m L})$ & MLC (mg/mL) \\
\hline E. coli & 125 & 250 \\
\hline Enterococcus faecalis & 125 & 250 \\
\hline Enterobacter aerogenes & 250 & 250 \\
\hline Bacillus licheniformis & 50 & 250 \\
\hline Bacillus stearothermophilus & 125 & 125 \\
\hline Pseudomonas aeruginosa & 50 & 125 \\
\hline Bordetella petrii & 50 & 250
\end{tabular}


Table 5. Antibiotic susceptibility test results

\begin{tabular}{|c|c|c|c|}
\hline Antibiotic & Resistant (\%) & Intermediate (\%) & Susceptible (\%) \\
\hline Co-trimoxazole ( $25 \mu \mathrm{g})$ & 75 & 25 & - \\
\hline Amikacin $(30 \mu \mathrm{g})$ & 62.5 & 25 & 12.5 \\
\hline Imipenem (10 $\mu \mathrm{g})$ & 50 & - & 50 \\
\hline Ceftazidime $(30 \mu \mathrm{g})$ & 50 & - & 50 \\
\hline Cefotaxime $(30 \mu \mathrm{g})$ & 62.5 & - & 37.5 \\
\hline Piperacillin/Tazobactam (100/10 $\mu \mathrm{g})$ & 37.5 & 12.5 & 50 \\
\hline Tetracycline $(30 \mu \mathrm{g})$ & 62.5 & - & 37.5 \\
\hline Chloramphenicol (30 $\mu \mathrm{g})$ & 75 & 12.5 & 12.5 \\
\hline Ciprofloxacin (5 $\mu \mathrm{g})$ & 37.5 & 12.5 & 50 \\
\hline Erythromycin $(15 \mu \mathrm{g})$ & 50 & 37.5 & 12.5 \\
\hline Doxycycline (30 $\mu \mathrm{g})$ & 50 & 12.5 & 37.5 \\
\hline Nitrofurantoin $(300 \mu \mathrm{g})$ & 37.5 & 12.5 & 50 \\
\hline
\end{tabular}

mophilus, Brevibacillus brevis, Bacillus licheniformis, and Bordetella petrii. The highest amylase activity belonged to Escherichia coli strains, Enterococcus faecalis, and Enterobacter aerogenes. Also, Brevibacillus brevis produced the least amount of enzyme. Enterococcus faecalis produced the least amount of protease, and other strains had moderate enzyme production. The result of the quantification of enzyme activity is given below.

\section{Discussion}

Compost is a decomposed organic matter which is rich in nutrients and microorganisms. It is a rich source of aerobic, anaerobic, mesophilic, and thermophilic bacteria. For the current study, compost was selected because of its rich source of pathogenic and non-pathogenic bacteria. After isolation and enrichment, eight different strains were saved on agar and broth. Among these or-

Table 6. Quantitative evaluation of enzyme activities

\begin{tabular}{cc}
\hline Protease Enzyme $(\mathrm{U} / \mathrm{mL})$ & Strains \\
\hline 4.1 & Bacillus stearothermophilus \\
\hline 5.4 & Bacillus licheniformis \\
3.2 & Bordetella petrii \\
\hline 5.7 & Strains \\
\hline Amylase enzyme $(\mathrm{U} / \mathrm{mL})$ & E. coli \\
\hline 0.09 & Enterococcus faecalis \\
\hline 0.07 & Enterobacter aerogenesis
\end{tabular}


ganisms, Pseudomonas aeruginosa, Enterobacter aerogenesis, Escherichia coli (ordinarily present in the human intestine but can cause diseases), and Bordetella petrii are Gram-negative pathogens. But, Enterococcus faecalis, Bacillus licheniformis, Brevibacillus brevis, Bacillus stearothermophilus are gram-positive bacteria. Among these, Bacillus licheniformis, Brevibacillus brevis are rarely pathogenic.

To determine the effect of rhamnolipid on isolated bacterial strains, the inhibitory zone was calculated using the disk diffusion method. The same method for determining the rhamnolipid effect on microbial strains was used in other studies $[39,40]$. The purpose of this method was to determine the susceptibility of bacterial strains to rhamnolipid. The disk diffusion method is used as a preevaluation method for novel antimicrobial agents [32]. About $1000 \mathrm{mg} / \mathrm{mL}$ of rhamnolipids showed the maximum inhibitory zone against different isolated strains, as shown in Table 3. Bacillus stearothermophilus has the maximum inhibitory zone of $31.5 \mathrm{~mm}$ among all other bacterial strains. The inhibitory zones showed the susceptibility of isolated bacterial strains for the rhamnolipid.

MIC and MBC were then determined to confirm further the susceptibility test for rhamnolipid. The result of the MIC is categorized as resistant, intermediate, and susceptible. If the concentration of rhamnolipid falls in the category of susceptible, it means that it is likely to inhibit the growth of that bacterium [41]. The rhamnolipid MIC results (Table 4) are compared with the antibiotic's standard MIC values (Table 5) provided by the US Clinical and Laboratory Standard Institute. When the data were analyzed with the help of descriptive statistics and frequency distribution tables, it was found that rhamnolipid is more effective than most of the synthetic antibiotics. It can also be proved by another study that the effectiveness of rhamnolipid as an antibiotic is much better than other antibiotics [42]. Rhamnolipid was more effective than most other antibiotics on bacterial strains of Bacillus stearothermophilus, Bacillus licheniformis, and Brevibacillus brevis. Also, rhamnolipids can be used as an excellent alternative against antibiotic-resistant pathogenic strains due to its antibacterial properties [25].

Similar results were seen in another study which proved that Gram-positive bacteria are more rhamnolipid sensitive with no effect on the $\mathrm{pH}$ [43]. However, doxycycline was more effective than rhamnolipid for Bacillus stearothermophilus and Brevibacillus brevis. In contrast, Bacillus licheniformis was more susceptible to ceftazidime than rhamnolipid.
Evaluation of amylase and protease activity showed that the strains differ in their enzymatic activity (Table 6). The bacterial strains of Bacillus stearothermophilus, Brevibacillus brevis, Bacillus licheniformis, and Bordetella petrii showed maximum protease activity. These bacteria are isolated from compost, so high proteolytic activity indicates their involvement in the Nitrogen cycle.

A similar study deduced that Alkalophilic bacillus isolated from natural host produced protease with high activity [44]. Whereas other strains, like Escherichia coli, Enterococcus faecalis, Enterobacter aerogenesis, and Pseudomonas aeruginosa, showed high amylase activity, which indicates that they use sugar as the source of energy. It can be proved with another study that explained that hemoglobin gene presence indicates the increased production of amylase in Escherichia coli strains [45]. One other study also explained the increased production and activity of enzymes from compost microorganisms $[46,47]$. Another study revealed that the rhamnolipids might improve the stability of an enzyme and its denaturation during heterogeneous hydrolysis of cellulose through enzymes. Additionally, rhamnolipids play a crucial role in removing pathogenic bacteria in composting because of their antibacterial function. It also promotes the quality of the composting products [1]

Bacterial strain for producing rhamnolipids is critically cost-effective for rhamnolipids production. Various efforts are needed for obtaining non-pathogenic strains with high production of rhamnolipid, including strains from the environment [48].

\section{Conclusion}

Microbiology trends are continuously changing because of new research, novel microbes, antibiotic resistance in microbes, and the side effects of synthetic antimicrobial agents. It is the need of the hour to find new alternatives to synthetic antimicrobials that are less toxic and have better inhibitory or bactericidal activity. During composting, different mesophilic and thermophilic pathogenic microbes grow in the organic compost, which increases the risk of a potential transfer of these pathogens through the vegetables and fruits grown in such pathogens (especially antibiotic-resistant strains) contaminated soil. Rhamnolipids are one such surfactant that is naturally produced by bacteria, which are less toxic and have antibacterial activity. Extensive research on these biosurfactants can improve the quality of the organic compost that could minimize the risk of contamination of pathogens through organic vegetables. Hence, the use of rhamnolipids can ensure the safety of 
organic farming products. Extensive research on these biosurfactants could help improve the chances of using them for successful microbial treatment due to their antibacterial properties.

\section{Ethical Considerations}

\section{Compliance with ethical guidelines}

All ethical principles were considered in this article.

Funding

This research was funded by University of Mohaghegh Ardabili, Ardabil.

\section{Conflict of interest}

The authors declared no conflict of interest.

\section{Acknowledgement}

The author would like to thank all those who participated in this study and the laboratory of the Department of Microbiology.

\section{References}

[1] Chong H, Li Q. Microbial production of rhamnolipids: Opportunities, challenges and strategies. Microb Cell Fact. 2017; 16(1):137. [DOI:10.1186/s12934-017-0753-2] [PMID] [PMCID]

[2] Abdel-Mawgoud AM, Lépine F, Déziel E. Rhamnolipids: Diversity of structures, microbial origins and roles. Appl Microbiol Biotechnol. 2010; 86(5):1323-36. [DOI:10.1007/s00253-010-24982] [PMID] [PMCID]

[3] Müller MM, Kügler JH, Henkel M, Gerlitzki M, Hörmann $B$, Pöhnlein $M$, et al. Rhamnolipids-next generation surfactants? J Biotechnol. 2012; 162(4):366-80. [DOI:10.1016/ij.jbiotec.2012.05.022] [PMID]

[4] Lotfabad T, Shahcheraghi F, Shooraj F. Assessment of antibacterial capability of rhamnolipids produced by two indigenous Pseudomonas aeruginosa strains. Jund. J. Microbiol. 2013; 6(1):29-35. [DOI:10.5812/jjm.2662]

[5] Twigg MS, Tripathi L, Zompra A, Salek K, Irorere VU, Gutierrez $\mathrm{T}$, et al. Identification and characterisation of short chain rhamnolipid production in a previously uninvestigated, nonpathogenic marine pseudomonad. Appl. Microbiol. Biotechnol. 2018; 102(19):8537-49. [DOI:10.1007/s00253-018-9202-3] [PMID] [PMCID]

[6] Rodrigues LR, Teixeira JA. Biomedical and therapeutic applications of biosurfactants. Adv Exp Med Biol. 2010; 672:75-87. [DOI:10.1007/978-1-4419-5979-9_6] [PMID]
[7] Irfan-Maqsood M, Seddiq-Shams M. Rhamnolipids: Well-characterized glycolipids with potential broad applicability as biosurfactants. Indust Biotechnol. 2014; 10(4):285-91. [DOI:10.1089/ ind.2014.0003]

[8] Hajfarajollah H, Mehvari S, Habibian M, Mokhtarani B, Noghabi KA. Rhamnolipid biosurfactant adsorption on a plasma-treated polypropylene surface to induce antimicrobial and antiadhesive properties. RSC Adv. 2015; 5(42):33089-97. [DOI:10.1039/ C5RA01233C

[9] Jadhav J, Dutta S, Kale S, Pratap A. Fermentative production of rhamnolipid and purification by adsorption chromatography. Prep Biochem Biotechnol. 2018; 48(3):234-41. [DOI:1.1080/1082 6068.2017.1421967] [PMID]

[10] Piljac T, Piljac G. Use of rhamnolipids as cosmetics. Patent no EP. 2007; 1056462. https://patentimages.storage.googleapis com/6a/68/1b/d84857c3250229/EP1056462B1.pdf

[11] Parry AJ, Parry NJ, Peilow C, Stevenson PS. Combinations of rhamnolipids and enzymes for improved cleaning. 2013 Patent no. EP, 2596087. https://patents.google.com/patent/ WO2012010406A1

[12] Sachdev DP, Cameotra SS. Biosurfactants in agriculture Appl Microbiol Biotechnol. 2013; 97(3): 1005-16. [DOI:10.1007/ s00253-012-4641-8] [PMID] [PMCID]

[13] Henkel M, Müller MM, Kügler JH, Lovaglio RB, Contiero J, Syldatk C, Hausmann R. Rhamnolipids as biosurfactants from renewable resources: Concepts for next-generation rhamnolipid production. Process Biochem. 2012; 47(8):1207-19. [DOI:10.1016/j.procbio.2012.04.018]

[14] Moya Ramírez I, Tsaousi K, Rudden M, Marchant R, Jurado Alameda E, García Román M, et al. Rhamnolipid and surfactin production from olive oil mill waste as sole carbon source. Bioresour Technol. 2015; 198:231-6. [DOI:10.1016/j.biortech.2015.09.012] [PMID]

[15] Borges WS, Moura AA, Coutinho Filho U, Cardoso VL, Resende MM. Optimization of the operating conditions for rhamnolipid production using slaughterhouse-generated industrial float as substrate. Braz J Chem Eng. 2015; 32(2):357-65. [DOI:10.1590/0104-6632.20150322s00003675]

[16] Nalini S, Parthasarathi R. Production and characterization of rhamnolipids produced by Serratia rubidaea SNAU02 under solid-state fermentation and its application as biocontrol agent. Bioresour Technol. 2014; 173:231-8. [DOI:10.1016/j.biortech.2014.09.051] [PMID]

[17] Zhao F, Han S, Zhang Y. Comparative studies on the structural composition, surface/interface activity and application potential of rhamnolipids produced by Pseudomonas aeruginosa using hydrophobic or hydrophilic substrates. Bioresour Technol. 2020; 295:122269. [DOI:10.1016/j.biortech.2019.122269] [PMID]

[18] Rekadwad B, Maske V, Khobragade CN, Kasbe PS. Production and evaluation of mono-and di-rhamnolipids produced by Pseudomonas aeruginosa VM011. Data Brief. 2019; 24:103890. [DOI:10.1016/j.dib.2019.103890] [PMID] [PMCID]

[19] Adegoke AA, Awolusi OO, Stenstrom TA. Organic fertilizers: Public health intricacies. In: Larramendy M, Soloneski $\mathrm{S}$, editors. Organic fertilizers-from basic concepts to applied outcomes. Rijeka, Croatia: Intech; 2016. p. 343-74 [DOI:10.5772/64195] 
[20] Miller C. Microbiological safety of organic fertilizers used for produce production [MSc. thesis]. South Carolina: Clemson University; 2011. https://tigerprints.clemson.edu/ all_theses/1123/

[21] Bernal MP, Sommer SG, Chadwick D, Qing Ch, Guoxue L, Michel Jr FC. Current approaches and future trends in compost quality criteria for agronomic, environmental, and human health benefits. Adv Agron. 2017; 144:143-233. [DOI:10.1016/bs.agron.2017.03.002]

[22] Ingham SC, Losinski JA, Andrews MP, Breuer JE, Breuer JR, Wood TM, et al. Escherichia coli contamination of vegetables grown in soils fertilized with noncomposted bovine manure: Garden-scale studies. Appl Environ Microbiol. 2004; 70(11):6420-7. [DOI:10.1128/AEM.70.11.6420-6427.2004] [PMID] [PMCID]

[23] Islam M, Doyle MP, Phatak SC, Millner P, Jiang X. Survival of Escherichia coli O157:H7 in soil and on carrots and onions grown in fields treated with contaminated manure composts or irrigation water. Food Microbiol. 2005; 22(1):63-70. [DOI:10.1016/j.fm.2004.04.007]

[24] Ruimy R, Brisabois A, Bernede C, Skurnik D, Barnat S, Arlet $\mathrm{G}$, et al. Organic and conventional fruits and vegetables contain equivalent counts of Gram-negative bacteria expressing resistance to antibacterial agents. Environ Microbiol. 2010; 12(3):608-15. [DOI:10.1111/j.1462-2920.2009.02100.x] [PMID]

[25] Shao B, Liu Z, Zhong H, Zeng G, Liu G, Yu M, et al. Effects of rhamnolipids on microorganism characteristics and applications in composting: A review. Microbiol Res. 2017; 200:33-44. [DOI:10.1016/j.micres.2017.04.005] [PMID]

[26] Haba E, Pinazo A, Jauregui O, Espuny MJ, Infante MR, Manresa A. Physicochemical characterization and antimicrobial properties of rhamnolipids produced by Pseudomonas aeruginosa 47T2 NCBIM 40044. Biotechnol Bioeng. 2003; 81(3):316-22. [DOI:10.1002/bit.10474] [PMID]

[27] Haba E, Bouhdid S, Torrego-Solana N, Marqués AM, Espuny MJ, García-Celma MJ, et al. Rhamnolipids as emulsifying agents for essential oil formulations: Antimicrobial effect against Candida albicans and methicillin-resistant Staphylococcus aureus. Int J Pharm. 2014; 476(1-2):134-41. [DOI:10.1016/j.ijpharm.2014.09.039] [PMID]

[28] Pourmazaheri H, Salehi Jouzani G, Nekouei MK, Tabatabaei M, Maali Amiri R, Soheilivand S, et al. [Identification and evaluation of enzymatic activities of some native bacteria isolated from composting process (Persian)]. Agri Biotech J. 2013; 5(1):1-11. [DOI:10.22103/JAB.2013.1145]

[29] Bergey DH, Holt JG. Bergey's manual of determinative bacteriology. Vol. 5: The Actinobacteria. New York: Springer; 2000. https://www.google.com/books/edition/Bergey_s_Manual_of_Systematic_Bacteriolo/66UMS7A2KisC?hl=en\&gb $\mathrm{pv}=0$

[30] Wayne PA. Clinical and laboratory Standards Institute: Performance standards for antimicrobial susceptibility testing: Twenty-Fifth Informational Supplement. CLSI document M100-S25. Clinical and Laboratory Standards Institute, 950 West Valley Road, Suite 2500, Wayne, Pennsylvania 19087 USA, 2015. https://clsi.org/standards/products/microbiology/documents/m24-supplement/

[31] Elshikh M, Moya-Ramírez I, Moens H, Roelants S, Soetaert W, Marchant R, et al. Rhamnolipids and lactonic sophorolipids: Natural antimicrobial surfactants for oral hy- giene. J Appl Microbiol. 2017; 123(5):1111-23. [DOI:10.1111/ jam.13550] [PMID]

[32] Bauer AW, Kirby WM, Sherris JC, Turck M. Antibiotic susceptibility testing by a standardized single disk method. Am J Clin Pathol. 1966; 45(4):493-6. [DOI:10.1093/ajcp/45.4_ ts.493] [PMID]

[33] Woods GL, Washington JA. Antibacterial susceptibility tests: dilution and disk diffusion methods, p. 1327-1341. In: Murray PR, Baron EJ, Pfaller MA, Tenover FC, and Yolken RC, editors. Manual of Clinical Microbiology. $6^{\text {th }}$ ed. Washington, DC.: American Society for Microbiology; 1995.

[34] Tenover FC. Antibiotic susceptibility testing. In: Schaechter M, editor. Encyclopedia of Microbiology. Amsterdam: Elsevier Science; 2009. [DOI:10.1016/B978-012373944-5.00239-X]

[35] Bagheri Lotfabad T, Shahcheraghi F, Shooraj F. Assessment of antibacterial capability of rhamnolipids produced by two indigenous pseudomonas aeruginosa strains. Jundishapur J Microbiol. 2013; 6(1):29-35. [DOI:10.5812/jjm.2662]

[36] Sarkar P, Chourasia R. Bioconversion of organic solid wastes into biofortified compost using a microbial consortium. Int J Recycl Org Waste Agric. 2017; 6(4):321-34. [DOI:10.1007/s40093-017-0180-8]

[37] Zeng GM, Shi JG, Yuan XZ, Liu J, Zhang ZB, Huang GH, et al. Effects of Tween 80 and rhamnolipid on the extracellular enzymes of Penicillium simplicissimum isolated from compost. Enzyme Microb Technol. 2006; 39(7):1451-6. [DOI:10.1016/j.enzmictec.2006.03.035]

[38] Naidu MA, Saranraj P. Bacterial amylase: A review. Int J Pharm Biol Arch. 2013; 4(2):274-87. https:/ /d1wqtxts1xzle7. cloudfront.net/

[39] Władyka B, Pustelny K. Regulation of bacterial protease activity. Cell Mol Biol Lett. 2008; 13(2):212-29. [DOI:10.2478/ s11658-007-0048-4] [PMID] [PMCID]

[40] Gomaa EZ. Antimicrobial activity of a biosurfactant produced by Bacillus licheniformis strain M104 grown on whey. Braz Arch Biol Technol. 2013; 56(2):259-68. [DOI:10.1590/ S1516-89132013000200011]

[41] Andrews JM. Determination of minimum inhibitory concentrations. Antimicrob Chemother. 2001; 48(Suppl 1):5-16. [DOI:10.1093/jac/48.suppl_1.5] [PMID]

[42] Elouzi AA, Gusbi AM, Elgerbi AM. Efficacy enhancement of hydrophobic antibiotics employing rhamnolipid as biosurfactant. J Am Sci. 2014; 10(1):93-8. http://free-journal. umm.ac.id/files/file/017_22880am100114_93_98.pdf

[43] Bharali P, Saikia JP, Ray A, Konwar BK. Rhamnolipid (RL) from Pseudomonas aeruginosa OBP1: A novel chemotaxis and antibacterial agent. Colloids Surf B Biointerfaces. 2013; 103:502-9. [DOI:10.1016/j.colsurfb.2012.10.064] [PMID]

[44] Gençkal H, Tari C. Alkaline protease production from alkalophilic Bacillus sp. isolated from natural habitats. Enzyme Microb Technol. 2006; 39(4):703-10. [DOI:10.1016/j.enzmictec.2005.12.004]

[45] Khosravi M, Webster DA, Stark BC. Presence of the bacterial hemoglobin gene improves $a$-amylase production of a recombinant Escherichia coli strain. Plasmid. 1990; 24(3):190-4. [DOI:10.1016/0147-619X(90)90002-T] 
[46] Shi JG, Zeng GM, Yuan XZ, Dai F, Liu J, Wu XH. The stimulatory effects of surfactants on composting of waste rich in cellulose. World J Microbiol Biotechnol. 2006; 22(11):1121-7. [DOI:10.1007/s11274-006-9152-2]

[47] Zeng G, Chen M, Zeng Z. Risks of neonicotinoid pesticides. Science. 2013; 340(6139):1403. [DOI:10.1126/ science.340.6139.1403-a] [PMID]

[48] Helle SS, Duff SJ, Cooper DG. Effect of surfactants on cellulose hydrolysis. Biotechnol Bioeng. 1993; 42(5):611-7. [DOI:10.1002/bit.260420509] [PMID] 
This Page Intentionally Left Blank 